Original Article

\title{
PRELIMINARY PHYTOCHEMICAL, ANTIOXIDANT AND ANTIMICROBIAL STUDIES OF FLACOURTIA JANGOMAS FRUITS
}

\author{
SUMIT DAS ${ }^{1}$, NURUZZAMAN DEWAN ${ }^{2}$, KAPIL JOYTI DAS ${ }^{1}$, DHRITISHMITA KALITA ${ }^{1}$ \\ ${ }^{1}$ Depertment of Pharmaceutical Chemistry, Girijananda Chowdhury Institute of Pharmaceutical Science, Azara, Hathkhowapara, \\ Guwahati-17, ${ }^{2}$ Girijananda Chowdhury Institute of Pharmaceutical Science, Azara, Hathkhuapara, Guwahati-17 \\ Email: sumitdas29j@gmail.com \\ Received: 28 Jan 2017, Revised and Accepted: 20 Apr 2017
}

\begin{abstract}
Objective: To determine phytochemical, antimicrobial and in vitro antioxidant activity of Flacourtia jangomas (Family: Flacourtiaceae)

Methods: The fruit extracts of the plant was taken for the phytochemical screening to identify the phytochemicals present in it. The extracts of the fruits were evaluated for antimicrobial activity against S. aureus and Escherichia coli by disc diffusion method. In vitro, antioxidant activity was performed by reducing power method, TBA method.
\end{abstract}

Results: The n-butanol extracts showed significant antimicrobial activity against all the strains as compared to the standard drug. The extracts also showed antioxidant activity against the standard ascorbic acid.

Conclusion: The extracts showed a high amount of antimicrobial activity and antioxidant activity.

Keywords: Antioxidant activity, Antimicrobial activity, Phytochemical screening

(C) 2017 The Authors. Published by Innovare Academic Sciences Pvt Ltd. This is an open access article under the CC BY license (http://creativecommons.org/licenses/by/4.0/]

DOI: http://dx.doi.org/10.22159/ijcpr.2017v9i4.20965

\section{INTRODUCTION}

India has an ancient heritage of traditional medicine. Indian traditional medicines are based on various systems including Ayurveda, Siddha and Unani. The evaluation of these are mainly based on phytochemical, pharmacological and allied approaches including various instrumental technique like chromatography, microscopy and others. Lot of efforts have been taken by the government and private sectors for the development of the traditional system based on these three methods [1].

Flacourtia jangomas is a plant belongs to the family of Flacourtiaceae growing in various parts of the world. It has been used as a traditional medicine for the treatment of different diseases in India [2]. Apart from its medicinal use, the plant is used for its edible fruits and lumber [3].

\section{Botanical aspects}

It is a tropical deciduous tree which grows to a height of $6-10 \mathrm{~m} \mathrm{[4].}$ The trunks and branches do not comprise of spikes but younger branches contains sharp, simple or divaricate spines. Leaves are narrow-ovate to ovate-oblong shape and rarely ovate-lance like or long obtuse-acuminate, base broadly wedge in shape. They are smooth and shining in the upper side. Leaf stalk is $6-8 \mathrm{~mm}$ long. Flowers are fragrant. Fruits are round in shapes with the size of about 15-25 mm. It's an edible fruit with juicy and fleshy in content.

Vernacular names

Assamese: Poniol

Bengali: Lukluki

English: Indian coffee plum

Hindi: Talispatri

Manipuri: Heitroi

Sanskrit: Sruvavrksha

Malayalam: Lubica

Tamil: Vaiyyankarai

\section{Distribution}

Flacourtia jangomas is a tree from the lowland areas cultivated in Southeast and East Asia [5]. The species is cultivated mainly in villages and then it was distributed throughout tropical regions in East Africa and tropical Asia. The species is also found in the warmer coastal districts of eastern Australia.

\section{MATERIALS AND METHODS}

\section{Collection and extraction of plant material}

The fruits of Flacourtia jangomas were collected from the localities in Guwahati, Kamrup (M), Assam during the month of march 2017. The F. jangomas were collected, shade dried, powdered mechanically and sieved through no. 20 mesh sieve. About $100 \mathrm{~g}$ of powdered fruits is extracted successively with petroleum ether (PEL), 60-80 C and then with dichloromethane (DCM), n-butanol (NB), ethyl acetate (EEL) and methanol (MEL). The extract collected was filtered and evaporated using rotary evaporator and stored in vacuum desiccators. The percentage yield of the extract is listed in table 1 .

Table 1: Percentage yield of various extracts

\begin{tabular}{ll}
\hline Extracts & \% yield \\
\hline PEL & 6.7 \\
DCM & 8.4 \\
NB & 9.8 \\
EEL & 9.5 \\
MEL & 9.2 \\
\hline
\end{tabular}

PEL: pet ether extract of $F$. jangomas fruits; CEL: chloroform extract of $F$. jangomas fruits; EEL: ethyl acetate extract of $F$. jangomas fruits; MEL: methanolic extract of $F$. jangomas fruits.

Phytochemical screening of the extracts

Phytochemical screening were carried out for NB, DCM, MEL extract of $F$. jangomas for the presence of phytochemical constituent like alkaloid, glycoside, tannin, amino acid, steroid, protein, flavonoid etc $[6,7]$. 


\section{In vitro antioxidant studies}

\section{Reducing power}

$1 \mathrm{ml}$ of methanolic extract $(100-400 \mu \mathrm{g} / \mathrm{ml})$, standard ascorbic acid dilutions $(20-100 \mu \mathrm{g} / \mathrm{ml})$ and control sample $(1 \mathrm{ml}$ distilled water instead of sample solution) was mixed with $2.5 \mathrm{ml}$ phosphate buffer solution ( $\mathrm{pH} 6.6$ ) and $2.5 \mathrm{ml}$ potassium ferricyanide (1\%). The final mixture was properly mixed and incubated at $50{ }^{\circ} \mathrm{C}$ for $20 \mathrm{~min}$. After incubation, the reaction mixture was rapidly cooled and mixed with $2.5 \mathrm{ml}$ of $10 \%$ trichloroacetic acid. It was centrifuged at $3000 \mathrm{rpm}$ for $10 \mathrm{~min}$. About $2.5 \mathrm{ml}$ of the supernatant was taken, and $2.5 \mathrm{ml}$ distilled water and $0.5 \mathrm{ml}$ of ferric chloride $(0.1 \%)$ were added, it was mixed well and allowed to stand for $10 \mathrm{~min}$. The absorbance was measured at $700 \mathrm{~nm}[8]$.

\section{Thiobarbituric acid method}

The test was conducted according to the method of Kikuzaki and Nakatani (1993) [9]. The same samples prepared for FTC method were used. To $2.0 \mathrm{ml}$ of the sample solution, $1.0 \mathrm{ml}$ of $20 \%$ aqueous trichloroacetic acid (TCA) and $2.0 \mathrm{ml}$ of aqueous thiobarbituric acid (TBA) solution were added. The final sample concentration was $0.02 \% \mathrm{w} / \mathrm{v}$. The mixture was placed in a boiling water bath for 10 min. After cooling, it was then centrifuged at $3000 \mathrm{rpm}$ for $20 \mathrm{~min}$. The absorbance of the supernatant was measured at $532 \mathrm{~nm}$. Antioxidant activity was recorded based on the absorbance of the final day of the FTC assay. Both methods (FTC and TBA) described antioxidant activity by percent inhibition:

$\%$ Inhibition $=($ Absorbance of control-Absorbance of sample)/Absorbance of control x 100

\section{Antimicrobial activity}

\section{Nutrient agar media}

Bacteriological media is a wide range of types. Nutrient Agar is a complex medium as it contains ingredients with unknown amounts or types of nutrients. Nutrient Agar contains Beef Extract (0.3\%), Peptone $(0.5 \%)$, Agar (1.5\%) and sodium chlorite $(0.5 \%)$ in water. Beef Extract is a commercially prepared dehydrated form of autolyzed beef and is supplied in the form of a paste. Peptone is the casein (milk protein) that has been digested with the enzyme pepsin. Peptone is dehydrated and supplied as a powder. Peptone and Beef Extract contain a mixture Amino and peptides of acids Beef Extract also contains water soluble digest products of all other macromolecules (nucleic acids, Fats, polysaccharides) as we as vitamins and trace minerals. Although we know and can define Beef Extract in these terms, each batch cannot be chemically defined. There are many media ingredients which are complex: yeast extract, tryptone, and others. The advantage of complex media is that they support the growth of wide range of microbes. Agar is purified from red algae in which it is an accessory polysaccharide (polygalacturonic acid) of their cell walls. Agar is added to microbial media only as a solidification agent. Agar for the most purpose is not nutrient value. Agar is an excellent solidification agent because it dissolves at near boiling but solidifies at $45^{\circ} \mathrm{C}$. Thus, one can prepare molten (liquid) agar at $45^{\circ} \mathrm{C}$, mix cells with it, and then allow it to solidify thereby trapping living cells. Below $45^{\circ} \mathrm{C}$ is a solid and remains so as the temperature is raised melting only when $>95^{\circ} \mathrm{C}$ is obtained.

\section{Procedure}

- Beef Extract, peptone were accurately weighted out and in 1000 $\mathrm{ml}$ of distilled water beef extract, peptone are added.

- $\mathrm{PH}$ was checked by using $\mathrm{pH}$ meter (pH 7.4), and finally, Agar was added to the flask.
- Boil the media to dissolve and allow it to cool a few minutes.

- The media is placed an autoclave for sterilization, while the agar is still warm, but not hot for $20 \mathrm{~min}$.

- Then the media is being taken from the autoclave and pour it is into the Petri dish with labeled as test and standard.

- The antimicrobial activities of the test agents were determined by measuring the diameter of the zone of inhibition.

Materials: Petri dish, Beef extract, Peptone, Agar, Ethanol, Distilled water.

Microorganism: Staphylococcus aureus and Escherichia coli.

Standard drug: Chloramphenicol.

\section{Disc diffusion method}

Antibacterial activity was done on nutrient agar media. $1 \mathrm{ml}$ of bacteria suspension was uniformly spread on the sterile nutrient agar media Petri dish. $1.5 \mathrm{mg}$ of each sample was dissolved in $10 \mathrm{ml}$ of the respective fractionation solvents. Sterile filter paper disc (Whatman no.1, diameter $6 \mathrm{~mm}$ ) was soaked with the extract solution and the solvent allowed to dry. The disc was placed on the nutrient agar media Petri dish inoculated with bacteria suspension and kept at $4{ }^{\circ} \mathrm{C}$ for $48 \mathrm{~h}$ to allow the extracts to diffuse into the media. The Petri dish was then placed in an incubator for $24 \mathrm{~h}$ at 37 ${ }^{\circ} \mathrm{C}$. At the end of the incubation period, the inhibition diameter was measured using calipers and expressed in millimeters. Chloramphenicol was used as standards. Positive antibacterial was established by the presence of measurable zones of inhibition.

\section{Minimum inhibitory concentration (MIC)}

The MIC was performed on hexane, ethyl acetate and methanol fractions, which on screening, had been found to be moderately active against most of the microbes tested. A sample weighing1 mg of each fraction was dissolved in $10 \mathrm{ml}$ of the fractionating solvent to form a solution having a concentration of $100 \mu \mathrm{g} / \mathrm{ml}$. Other concentrations were obtained by taking $0.1,0.2,0.3,0.4,0.5,0.6,0.7$, and $0.8 \mathrm{ml}$ of the solution containing $100 \mu \mathrm{g} / \mathrm{ml}$ and adding $1 \mathrm{ml}$ of the solvent separately to obtain new solutions with concentrations $10 \mu \mathrm{g} / \mathrm{ml}$, $20 \mu \mathrm{g} / \mathrm{ml}, \quad 30 \mu \mathrm{g} / \mathrm{ml}, 40 \mu \mathrm{g} / \mathrm{ml}, \quad 50 \mu \mathrm{g} / \mathrm{ml}, \quad 60 \mu \mathrm{g} / \mathrm{ml}, 70 \mu \mathrm{g} / \mathrm{ml}$ and $80 \mu \mathrm{g} / \mathrm{ml}$ respectively. The concentration necessary to cause minimum inhibition was then determined.

The medicinal properties of plant extracts normally depend upon the presence of active compounds possessing specific functional groups that are soluble only in solvents of a particular polarity. The active compounds in the extract of the fruits of Flacourtia jangomas were shown moderately active against E. coli, the gram-positive bacteria and S. aureus, the gram-negative bacteria as compared to the standard.

The outcome found for the antimicrobial of Flacourtia jangomas are discussed in detail in this chapter. It was shown that the significant activities for antimicrobial properties.

\section{RESULTS AND DISCUSSION}

\section{Preliminary phytochemical screening}

Methanolic, n-butanol and DCM extract Flacourtia jangomas fruits showed the presence of phenolics, steroids, and flavonoids also glycosides (except DCM) shown in table 1. Medicinal plants are a great source of active constituents for the development of new therapeutic compounds.

Table 2: Results of preliminary phytochemical screening

\begin{tabular}{|c|c|c|c|}
\hline Name of the test & Methanolic extract & N-butanol extract & DCM extract \\
\hline Glycoside & + & + & - \\
\hline Alkaloid & - & _- & - \\
\hline Flavonoid & + & + & + \\
\hline Protein & - & - & - \\
\hline Amino acid & - & - & - \\
\hline Tannin & - & - & - \\
\hline Steroid & + & + & + \\
\hline Phenolics & + & + & + \\
\hline
\end{tabular}


Table 3: Reducing power assay

\begin{tabular}{llllllll}
\hline S. No. & Sample & Activity & $\mathbf{2 0} \boldsymbol{\mu g} / \mathbf{m l}$ & $\mathbf{4 0} \boldsymbol{\mu g} / \mathbf{m l}$ & $\mathbf{6 0} \boldsymbol{\mu g} / \mathbf{m l}$ & $\mathbf{8 0} \boldsymbol{\mu g} / \mathbf{m l}$ & $\mathbf{1 0 0} \boldsymbol{\mu g} / \mathbf{m l}$ \\
\hline & Standard: (Ascorbic acid) & & $1.636 \pm 0.022$ & $2.389 \pm 0.020$ & $3.127 \pm 0.030$ & $3.459 \pm 0.017$ & $4.124 \pm 0.040$ \\
1 & Test (DCM extract) & RP & $1.435 \pm 0.020$ & $2.010 \pm 0.018$ & $3.022 \pm 0.022$ & $3.154 \pm 0.012$ & $4.088 \pm 0.039$ \\
2 & Test (NB extract) & RP & $1.468 \pm 0.019$ & $2.330 \pm 0.020$ & $3.124 \pm 0.025$ & $3.359 \pm 0.010$ & $4.115 \pm 0.030$ \\
3 & Test (EA extract) & RP & $1.226 \pm 0.011$ & $1.505 \pm 0.014$ & $3.026 \pm 0.012$ & $3.227 \pm 0.006$ & $4.005 \pm 0.022$ \\
4 & Test (Methanol extract) & RP & $1.433 \pm 0.020$ & $2.220 \pm 0.022$ & $3.044 \pm 0.026$ & $3.339 \pm 0.015$ & $4.006 \pm 0.042$ \\
\hline
\end{tabular}

IC50 value in reducing power assay $254.5 \mu \mathrm{g} / \mathrm{ml}$ for extract and 43.7 $\mu \mathrm{g} / \mathrm{ml}$ for standard (table 5). Substances, which have reduction potential, react with potassium ferricyanide $(\mathrm{Fe} 3+)$ to form potassium ferrocyanide $(\mathrm{Fe} 2+)$, which then reacts with ferric chloride to form a ferric ferrous complex that has an absorption maximum at $700 \mathrm{~nm}$. These assays are known as a robust and useful method for measuring a wide concentration range of antioxidant activities and capacities [10].

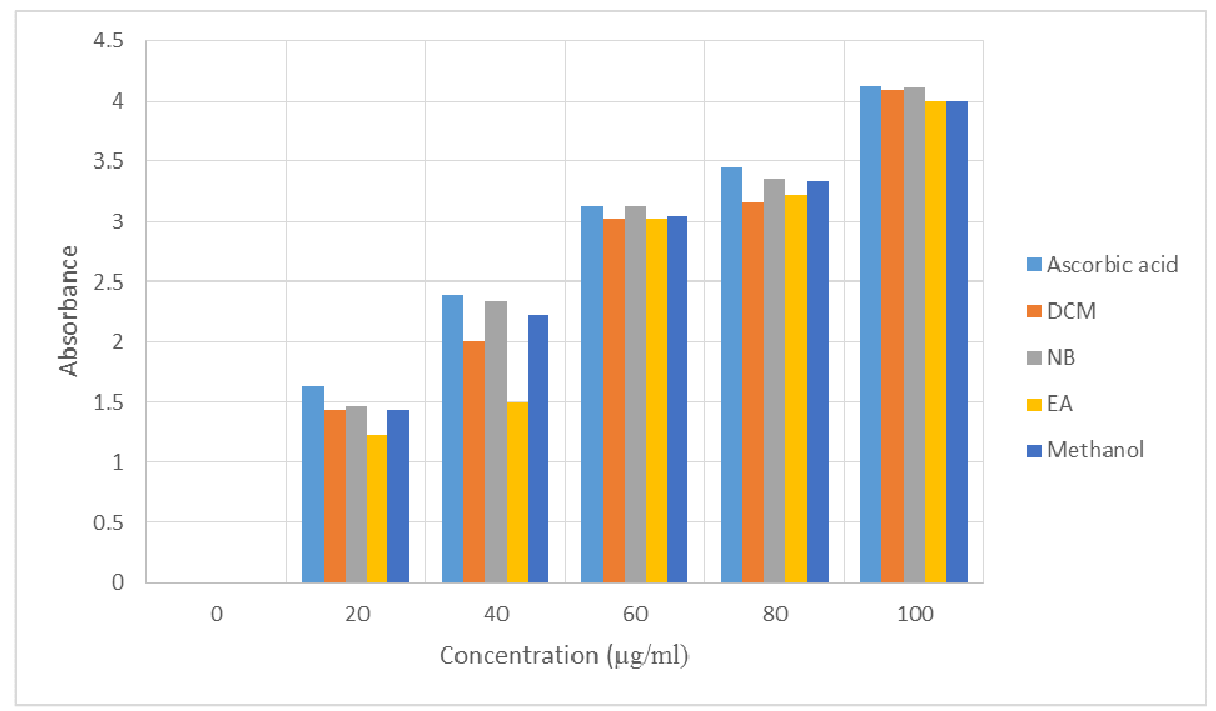

Fig. 1: Reducing power activity of different extract of F. jangomas

\section{Thiobarbituric assay}

The test was conducted according to the method of Kikuzaki and Nakatani (1993) [9]. The same samples prepared for FTC method were used. To $2.0 \mathrm{ml}$ of the sample solution, $1.0 \mathrm{ml}$ of $20 \%$ aqueous trichloroacetic acid (TCA) and $2.0 \mathrm{ml}$ of aqueous thiobarbituric acid
(TBA) solution were added. The final sample concentration was $0.02 \% \mathrm{w} / \mathrm{v}$. The mixture was placed in a boiling water bath for 10 min. After cooling, it was then centrifuged at $3000 \mathrm{rpm}$ for $20 \mathrm{~min}$. The absorbance of the supernatant was measured at $532 \mathrm{~nm}$. Antioxidant activity was recorded based on the absorbance of the final day of the FTC assay.

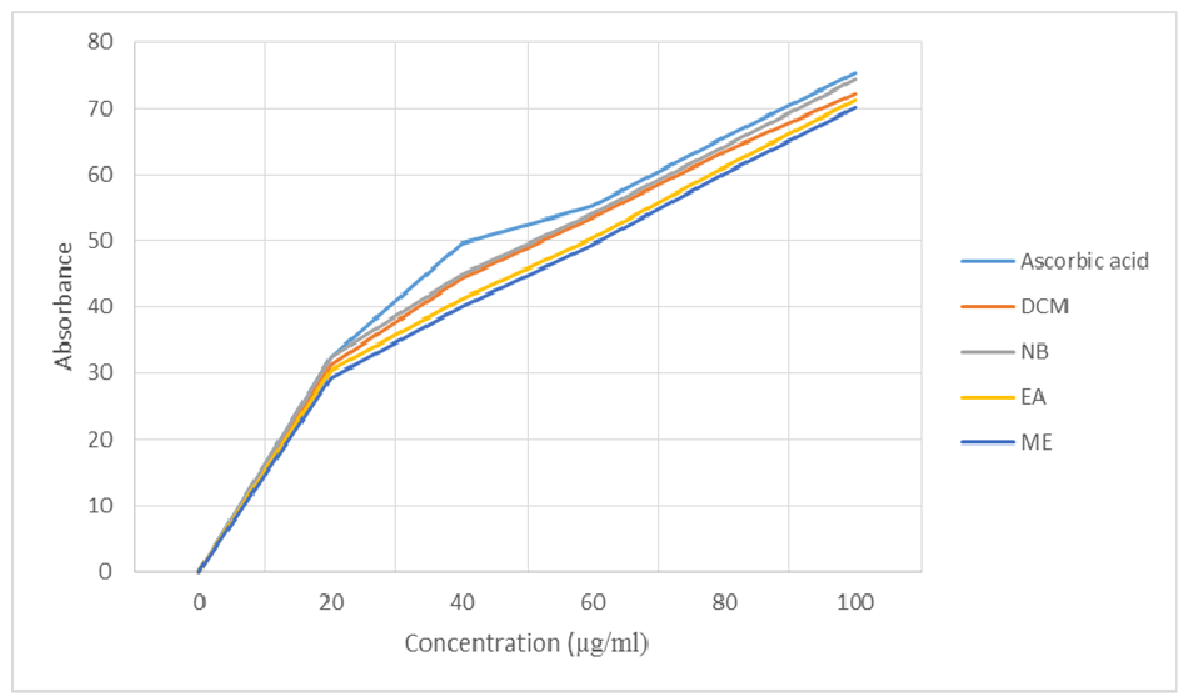

Fig. 2: TBA activity of different extract of $F$. jangomas 
Das et al.

Table 4:

\begin{tabular}{|c|c|c|c|c|c|c|c|}
\hline S. No. & Sample & Activity & $20 \mu \mathrm{g} / \mathrm{ml}$ & $40 \mu \mathrm{g} / \mathrm{ml}$ & $60 \mu \mathrm{g} / \mathrm{ml}$ & $80 \mu \mathrm{g} / \mathrm{ml}$ & $100 \mu \mathrm{g} / \mathrm{ml}$ \\
\hline & Standard: (Ascorbic acid) & & $32.35 \pm 0.001$ & $49.67 \pm 0.002$ & $55.22 \pm 0.001$ & $65.60 \pm 0.05$ & $75.47 \pm 0.01$ \\
\hline 1 & Test (DCM extract) & TBA & $31.23 \pm 0.011$ & $44.34 \pm 0.002$ & $53.45 \pm 0.101$ & $63.45 \pm 0.04$ & $72.34 \pm 0.011$ \\
\hline 2 & Test (NB extract) & TBA & $32.44 \pm 0.101$ & $45 . \pm 0.001$ & $54.12 \pm 0.005$ & $64.34 \pm 0.05$ & $74.33 \pm 0.02$ \\
\hline 3 & Test (EA extract) & TBA & $30.46 \pm 0.002$ & $41.20 \pm 0.004$ & $50.32 \pm 0.001$ & $61.23 \pm 0.07$ & $71.23 \pm 0.031$ \\
\hline 4 & Test (Methanol extract) & TBA & $29.23 \pm 0.012$ & $40.08 \pm 0.121$ & $49.34 \pm 0.022$ & $60.11 \pm 0.05$ & $70.12 \pm 0.22$ \\
\hline
\end{tabular}

\section{Antimicrobial activity}

The Methanolic extract, ethyl acetate extract and N-butanol extract of Flacourtia jangomas were tested for antibacterial activities against a number of both gram positive and gram negative bacteria.
Standard Chloramphenicol discs (10 $\mu \mathrm{g} /$ disc) were used for the comparison purpose. The antimicrobial activities of the methanolic extract, ethyl acetate extract and N-butanol extract from Flacourtia jangomas were tested in the present study. The results were given gradually in table 4, table 5 and table 6 .

Table 5: MIC of the methanolic extract

\begin{tabular}{|c|c|c|c|}
\hline \multirow[t]{2}{*}{ Test sample } & \multirow{2}{*}{$\begin{array}{l}\text { Concentration } \\
(\mu \mathrm{g} / \mathrm{ml})\end{array}$} & \multicolumn{2}{|c|}{ Diameter zone of inhibition (mm) } \\
\hline & & Gram-ve bacteria (E. Coli) & Gram+ve bacteria (S. aureus) \\
\hline \multirow[t]{8}{*}{ Methanolic Extract } & 10 & 1.1 & 2.2 \\
\hline & 20 & 1.5 & 3.1 \\
\hline & 30 & 2.3 & 5.5 \\
\hline & 40 & 4.2 & 7.1 \\
\hline & 50 & 6.1 & 7.9 \\
\hline & 60 & 6.9 & 9.3 \\
\hline & 70 & 7.5 & 9.7 \\
\hline & 80 & 8.7 & 10 \\
\hline Standard & 10 & 15.1 & 15.1 \\
\hline
\end{tabular}

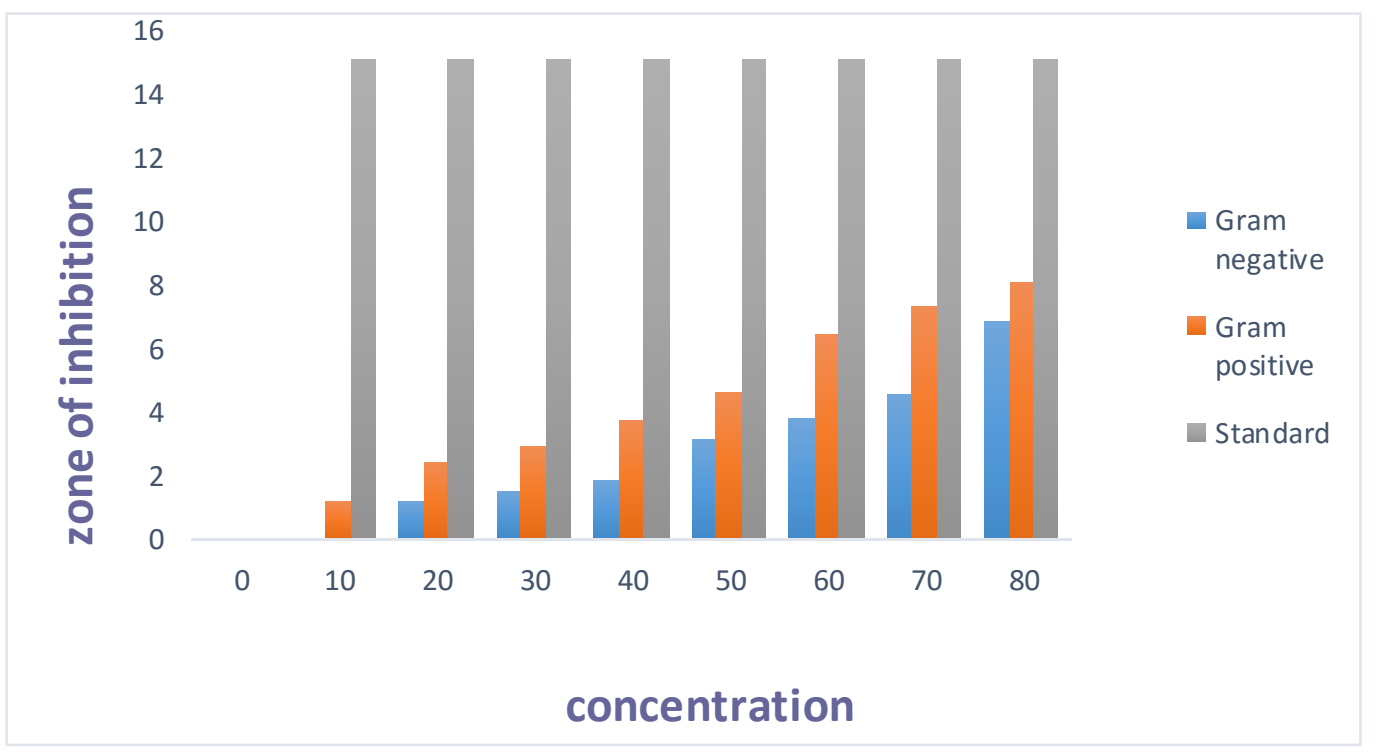

Fig. 3: Effect on antimicrobial activity of methanolic extract of $F$. jangomas

Table 6: MIC of the ethyl acetate extract

\begin{tabular}{llll}
\hline Test sample & Concentration $(\boldsymbol{\mu g} / \mathbf{m l})$ & \multicolumn{2}{l}{ Diameter zone of inhibition $(\mathbf{m m})$} \\
\cline { 3 - 4 } & & Gram-ve bacteria (E. Coli) & Gram+ve bacteria (S. aureus) \\
\hline Ethyl Acetate & 10 & 0.6 & 2.0 \\
& 20 & 1.0 & 2.6 \\
& 30 & 1.9 & 3.9 \\
& 40 & 2.1 & 6.0 \\
& 50 & 4.9 & 6.7 \\
& 60 & 5.4 & 8.8 \\
Standard & 70 & 6.3 & 9.0 \\
& 80 & 7.9 & 9.7 \\
\hline
\end{tabular}




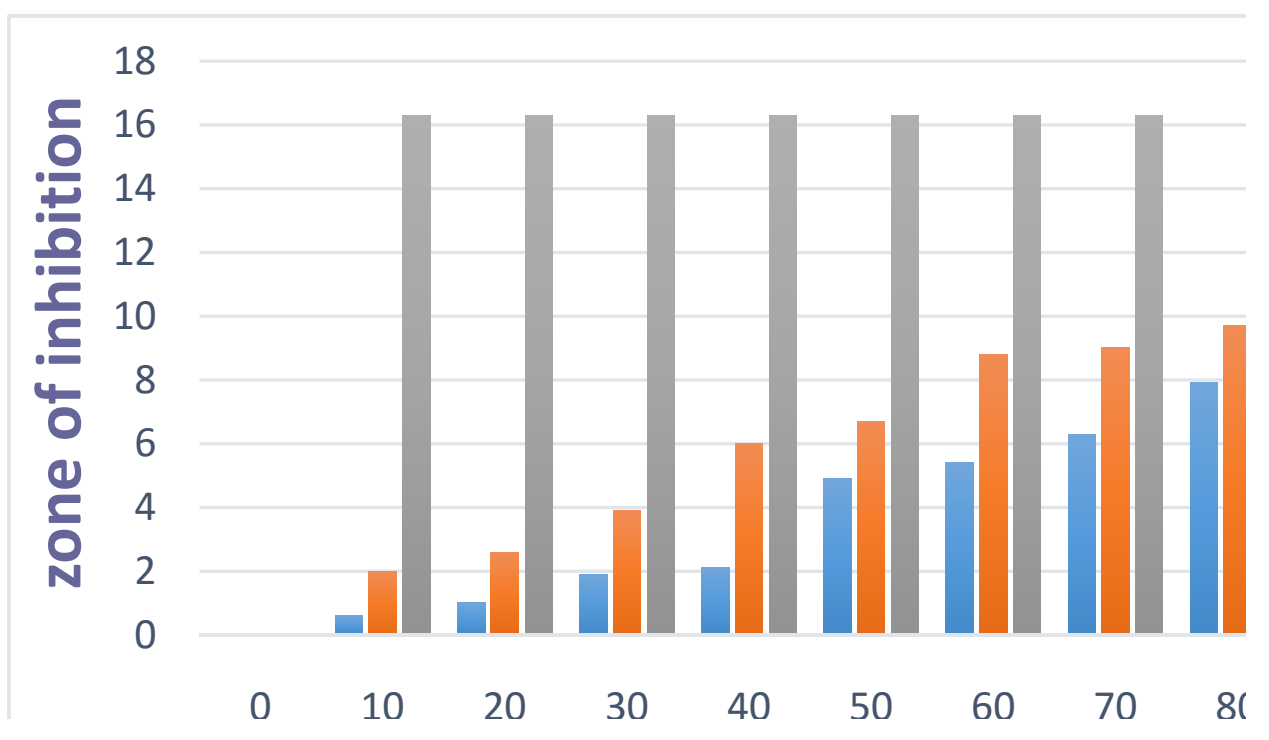

Fig. 4: Effect on Antimicrobial activity of ethyl acetate extract of $F$. jangomas

Table 7: MIC of the n-butanol

\begin{tabular}{|c|c|c|c|}
\hline \multirow[t]{2}{*}{ Test sample } & \multirow[t]{2}{*}{ Concentration $(\mu \mathrm{g} / \mathrm{ml})$} & \multicolumn{2}{|c|}{ Diameter zone of inhibition (mm) } \\
\hline & & Gram-ve bacteria (E. Coli) & Gram+ve bacteria (S. aureus) \\
\hline \multirow[t]{8}{*}{ N. butanol extract } & 10 & None & 1.2 \\
\hline & 20 & 1.2 & 2.4 \\
\hline & 30 & 1.5 & 2.9 \\
\hline & 40 & 1.8 & 3.7 \\
\hline & 50 & 3.1 & 4.6 \\
\hline & 60 & 3.8 & 6.4 \\
\hline & 70 & 4.5 & 7.3 \\
\hline & 80 & 6.8 & 8.1 \\
\hline Standard & 10 & 14 & 14 \\
\hline
\end{tabular}

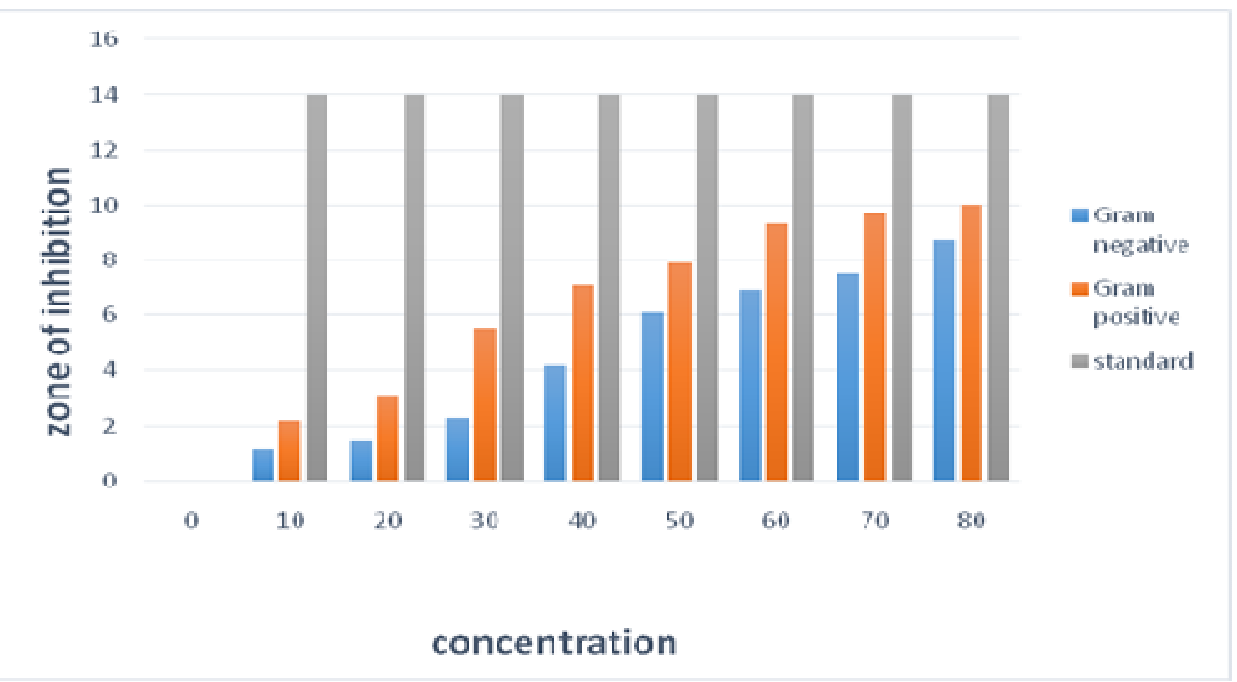

Fig. 5: Effect on antimicrobial activity of $\mathrm{N}$-butanol extract of $\mathrm{F}$. jangomas

\section{DISCUSSION}

Various chemical constituents such as glycosides, flavonoids, phenolics and steroids were found. Phenolics, steroids and flavonoids were present in all the extracts whereas proteins, alkaloids and amino acids are absent. Free radicals are harmful as they can participate in superfluous side reactions due to their chain reaction properties which resulting in cell damage, blemishing of food, degradation of various materials like rubber, gasoline etc.
Antioxidants are that molecules which can halt these chain reactions by removing free radical intermediates. Phenolic compounds are responsible for antioxidant properties due to their ability to donate electron resulting in the conversion of highly reactive free radicals to nonreactive stable molecules.

Phenolic compounds may be of three types-non-flavonoids like hydroxybenzoic acid, flavonoids like flavones, flavonols, flavanones etc and type three is tannins. The n-butanol extract of Flacourtia 
jangomas showed a high amount of antioxidant activity in reducing power assay and thiobarbituric assay which is because of the presence of flavonoids. N-butanol extract exhibited a proportional increase of absorbance along with the concentration which proves the presence of some active compounds those are capable of reacting with free radicals and converting them to stable nonreactive form as well as terminating chain reactions. The indiscriminate use of antibiotics has developed many resistant micro-organisms creating immense clinical problems in the treatment of infectious diseases such as those caused by multi-drug resistant $S$. aureus and $E$. coli. Therefore there is a need to develop alternative antimicrobial agents for the treatment of these infectious diseases. There are many investigations carried on the aerial parts (leaves) of Flacourtia jangomas by various workers, however, not many studies are available on the antimicrobial and pharmacological potential of Flacourtia jangomas fruits.

\section{CONCLUSION}

From these investigations, it may be concluded that the n-butanol fruits extract of F. jangomas showed potential antioxidant, in different established models. These results also justify the use of leaves in traditional medicines. It is important to isolate and characterize the active compounds responsible for these activities through LC-MS and other advanced techniques.

\section{CONFLICT OF INTERESTS}

\section{Declare none}

\section{REFERENCES}

1. Mukherjee PK. Quality control of herbal drugs an approach to the evaluation of botanical. Pharm Publishers 2010;4:2-17.
2. Ahmed J, Wizarat K, Shamsuddin KM, Zaman A, Connolly JD. Jangomolide, a novel limonoid from Flacourtia jangomas. Phytochemistry 1984;6:1269-70.

3. KS Krishnan Marg. Flacourtia comm. (Flacourtiaceae). In the Wealth of India: Raw Materials, CSIR, New Delhi; 1956;4:42-4.

4. Quiner Y, Zmarzty S. Flora of China. Available from; http://www.EFloras.org.St.Louis, MO and Harvard University Herbaria, Cambridge, MA: Missouri Botanical Garden Press; 2007. p. 118-21.

5. Talukdar C, Saha S, Adhikari S, Mondal HK, Islam MDK, Anisuzzman MD. Evaluation of antioxidant, analgesic, and antidiarrhoeal activity of Flacourtia jangomas (Lour.) raeusch leaves. Pharmacologyonline 2012;3:20-8.

6. Trease GE, Evans MC. Textbook of pharmacognosy. 12th ed. London: Bailier Tindall; 2002. p. 343-82.

7. Harborne JB. Phytochemical methods. A guide to modern techniques of plant analysis. India: Springer; 1998. p. 49-120.

8. Maisarah AM, Nurul Amira B, Asmah R, Fauziah O. Antioxidant analysis of different parts of Carica papaya. Int Food Res J 2013;20:1043-8.

9. Kikuzaki H, Nakatani N. Antioxidant effects of some ginger constituents. J Food Sci 1993;58:1407-10.

10. Bors W, Michel C. Antioxidant capacity of flavanols and gallate esters: pulse radiolysis studies. Free Radical Biol Med 1999;27:1413-26.

\section{How to cite this article}

- Sumit Das, Nuruzzaman Dewan, Kapil Joyti Das, Dhritishmita Kalita. Preliminary phytochemical, antioxidant and antimicrobial studies of Flacourtia jangomas fruits. Int J Curr Pharm Res 2017;9(4):86-91. 